\title{
Parasitism of cassava mealybug by Anagyrus lopezi: Effects of varying host and parasitoid densities
}

\author{
MUHAMMAD ZAINAL FANANI ${ }^{1, \vartheta}$, AUNU RAUF ${ }^{2}$, NINA MARYANA ${ }^{2}$, ALI NURMANSYAH ${ }^{2}$, \\ DADAN HINDAYANA ${ }^{2}$ \\ ${ }^{1}$ Program of Entomology, Graduate School, Institut Pertanian Bogor. Jl. Kamper, Kampus IPB Darmaga, Wing 7 Level 5, Bogor 16680, West Java, \\ Indonesia. Tel.: +62-251-8629364, Fax.: +62-251-8629362, `email: muhammaduzainale@ gmail.com \\ ${ }^{2}$ Department of Plant Protection, Faculty of Agriculture, Institut Pertanian Bogor. Jl. Kamper, Kampus IPB Darmaga, Wing 7 Level 5, Bogor 16680, \\ West Java, Indonesia
}

Manuscript received: 15 July 2020. Revision accepted: 30 September 2020.

\begin{abstract}
Fanani MZ, Rauf A, Maryana N, Nurmansyah A, Hindayana D. 2020. Parasitism of cassava mealybug by Anagyrus lopezi: Effects of varying host and parasitoid densities. Biodiversitas 21: 4973-4980. The solitary endoparasitoid Anagyrus lopezi (De Santis) (Hymenoptera: Encyrtidae) was introduced into Indonesia in 2014 to control the cassava mealybug, Phenacoccus manihoti MatileFerrero (Hemiptera: Pseudococcidae). The objectives of this study were to understand the influence of host and parasitoid den sities on functional response and mutual interference of the parasitoid, by altering either the host or parasitoid density while keeping the other constant. The effects of host and parasitoid densities on parasitism, superparasitism, progeny production, and sex ratio were also assessed. Logistic regression was used to determine the shape of the functional response. Nonlinear least-squares regression was used to estimate the attack rate (a) and handling time $\left(\mathrm{T}_{\mathrm{h}}\right)$. Nicholson's model and linear regression were used to determine per capita searching efficiency and interference coefficient, respectively. The logistic regression results suggested a Holling type II functional response to changing host densities, with an estimated attack rate $(a)$ and handling time $\left(\mathrm{T}_{\mathrm{h}}\right)$ were $0.037 \mathrm{~h}^{-1}$ and $1.19 \mathrm{~h}$, respectively. The estimated maximum number of mealybugs parasitized over 24-h period was 20.2 mealybugs. The wasp-mealybug ratio and offspring production increased significantly from $1: 2$ to $1: 100$ and from 1.35 to 10.45 , respectively. However, the per capita number of parasitization decreased significantly from 14.20 to 4.37 , with the increase in parasitoid density from 1 to 8 . Searching efficiency of the parasitoid decreased significantly with increasing parasitoid density, with a mutual interference constant (m) of -0.52 .
\end{abstract}

Keywords: Anagyrus lopezi, functional response, mutual interference, parasitoid

\section{INTRODUCTION}

The cassava mealybug, Phenacoccus manihoti MatileFerrero (Hemiptera: Pseudococcidae), is the most important insect pest of cassava in the world (Bellotti et al. 2012), causing a threat to the food and livelihood of poor farmers (Yonow et al. 2017). The pest is native to South America, but it was accidentally introduced into Africa in the early 1970s (Bellotti et al. 2012) and Asia in 2008 (Winotai et al. 2010; Parsa et al. 2012; Graziosi et al. 2015), including Indonesia (Muniappan et al. 2011). To control the pest, the host-specific solitary endoparasitoid Anagyrus lopezi (De Santis) (Hymenoptera: Encyrtidae) was introduced from Paraguay to Nigeria in 1981 (Bellotti et al. 2012), and subsequently to Thailand in 2009 (Winotai et al. 2010) and to Indonesia in 2014 (Wyckhuys et al. 2014). The introduction of this parasitoid into Africa reduced yield losses from as high as $80 \%$ to $5-10 \%$, becoming a highly-successful case of classical biological control (Bellotti et al. 2012). A similar outcome was also reported from its introductions to Southeast Asian countries (Wyckhuys et al. 2018). The parasitoid successfully established and spread through several countries in Southeast Asia, suppressing mealybug populations and attaining a parasitism level of $10-57 \%$ (Le et al. 2018;
Thancharoen et al. 2018; Wyckhuys et al. 2018; Fanani et al. 2019).

The success of a parasitoid as an efficient biocontrol agent depends on its density responsiveness to the target species, which is related to the searching efficiency of the parasitoid (Saini and Sharma 2018). One of the best ways to determine the searching abilities of a parasitoid is to study its functional response to the target species (Luo et al. 2014; Poncio et al. 2016). Functional response characterizes a relationship between the rate of attack by a single parasitoid and its host density. Thus the knowledge of functional response is important to understand the parasitoid regulatory effect on the host population (Feng et al. 2014; Luo et al. 2014; Saini and Sharma 2018). The functional response depends on handling time $\left(\mathrm{T}_{\mathrm{h}}\right.$ : the time that a parasitoid needs to parasitize a single host) and searching efficiency (a: the rate at which a parasitoid searches). Three basic types of functional responses have been described for arthropods. The type I response is a linear increase in host numbers attacked with an increase in host population density. The relationship between the attack efficiency and host population density in the type II response is curvilinear, and in type III takes the form of a sigmoid curve (Hassell 2000; Rosenbaum and Rall 2018; Tazerouni et al. 2019; Dunn and Hovel 2020). 
Besides information on how individual parasitoids respond to host density, it is also important to know how they affect each other while searching for suitable hosts (Skovgard and Nachman 2015). Thus, when the number of conspecific females occurring in a patch with a fixed number of hosts increases, it is expected that the time each individual parasitoid spends searching on the patch will decline, thereby reducing their attack efficiency (Hassell 2000). Consequently, this will cause a reduction in the number of hosts parasitized per female parasitoid. Such density-dependent interactions and behavioral responses caused by interference among natural enemies of the same species leading to a reduction in the per capita attack rate are known as mutual interference (Hassell 2000).

While functional response describes the density responsiveness of the parasitoid to its host, mutual interference describes the extrinsic competition among the foraging conspecific female parasitoids (Saini and Sharma 2018). Studies of the functional response and mutual interference of various parasitoids have been reported, such as for Dolichogenidea tasmanica Cameron (Hymenoptera: Braconidae) attacking Epiphyas postvittana Walker (Lepidoptera: Tortricidae) (Yazdani and Keller 2015), Goniozus nephantidis Muesebeck (Hymenoptera: Bethylidae) attacking Opisina arenosella Walker (Lepidoptera: Oeccophoridae) (Sreenivas and Hardy 2016), Spalangia cameroni Perkins (Hymenoptera: Pteromalidae) attacking Stomoxys calcitrans L. (Diptera: Muscidae) (Skovgard and Nachman 2015). With respect to A. lopezi, the functional response and mutual interference have not been studied. The objectives of this study were to investigate the functional response and mutual interference of $A$. lopezi by either altering the parasitoid or host density while maintaining the other constantly. The effect of parasitoid and host densities on progeny production, sex ratio, parasitism, and superparasitism of A. lopezi were also evaluated. The findings of the present study may provide a better understanding of host-parasitoid interactions to improve biological control of the cassava mealybug.

\section{MATERIALS AND METHODS}

Studies were conducted from August 2018 until January 2019 in the Laboratory of Insect Bionomy and Ecology, Faculty of Agriculture, IPB University. Experiments were carried out at $27 \pm 2{ }^{\circ} \mathrm{C}, 60 \pm 3 \%$ relative humidity $(\mathrm{RH})$, and under a photoperiod of 12: $12 \mathrm{~h}$ (L:D).

\section{Rearing of mealybugs and parasitoids}

Anagyrus lopezi was reared on cassava plants, supporting the third instar population of $P$. manihoti as described by Fanani et al. (2020). Ten days after the release of the parasitoids, mummies were collected from the cassava plants and placed individually in gelatin capsules. Mummies were observed daily, and emerged parasitoids were used in experiments.

\section{Effect of host density on parasitism, progeny, and sex ratio}

Third instar mealybug nymphs at densities of 2, 5, 10, 20,50 , or 100 and placed on a leaf of waterleaf (Talinum triangulare (Jack.) Wild) were exposed to a single twoday-old mated $A$. lopezi female in a petri dish $(\mathrm{d}=9 \mathrm{~cm}, \mathrm{~h}$ $=1.5 \mathrm{~cm}$ ) and fed with a drop of $10 \%$ honey on the base of the petri dish. The parasitoids were allowed to forage and oviposit for $24 \mathrm{~h}$, and then the adult parasitoids were removed. The exposed mealybugs were then transferred onto waterleaf cutting and placed into a cage made of a transparent plastic cylinder $(\mathrm{d}=3 \mathrm{~cm}, \mathrm{~h}=3.5 \mathrm{~cm})$ with the top covered with nylon mesh. Seven days later, the number of mealybugs mummified (parasitized) were counted and collected. Each mummy was placed inside a gelatin capsule for adult emergence. The number of parasitoid adults emerged was recorded and separated based on sex. Each treatment was replicated 10 times. To determine the type of functional response, the data were fitted to the logistic regression as follows:

$$
\frac{\mathrm{N}_{\mathrm{a}}}{\mathrm{N}_{0}}=\frac{\exp \left(\mathrm{P}_{0}+\mathrm{P}_{1} \mathrm{~N}_{0}+\mathrm{P}_{2} \mathrm{~N}_{0}^{2}+\mathrm{P}_{3} \mathrm{~N}_{0}^{3}\right)}{1+\exp \left(\mathrm{P}_{0}+\mathrm{P}_{1} \mathrm{~N}_{0}+\mathrm{P}_{2} \mathrm{~N}_{0}^{2}+\mathrm{P}_{3} \mathrm{~N}_{0}^{3}\right)}
$$

Where $\mathrm{Na}$ is the number of hosts parasitized, No is the initial host density, $\mathrm{Na} / \mathrm{No}$ is the proportion of the total mealybugs parasitized, and $\mathrm{P}_{0}, \mathrm{P}_{1}, \mathrm{P}_{2}$, and $\mathrm{P}_{3}$ are the parameters to be estimated. These parameters were calculated using the PROC CATMOD in SAS software (SAS Institute 2015). Where the cubic equation resulted in a nonsignificant cubic parameter $\left(\mathrm{P}_{3}\right)$, the model was reduced by eliminating the cubic term from the equation, and the other parameters were retested (Juliano 2001). A significant negative or positive linear coefficient $\left(\mathrm{P}_{1}\right)$ of the logistic regression model indicates type II or III of functional response, respectively.

Following this analysis and since our data fit a type II functional response (see Results and Discussion), we used a Holling's disc equation (Hassell 2000) as follows:

$$
\mathrm{Na}=\mathrm{aNoT} /\left(1+\mathrm{aT}_{h} \mathrm{No}\right)
$$

Where $\mathrm{Na}$ is the number of hosts parasitized, No is the initial host density, a is a constant expressing attack efficiency, $\mathrm{T}$ is the duration of the experiment (i.e., $24 \mathrm{~h}$ ), and $T_{h}$ is the handling time (h) per host. The parameters a and $T_{h}$ were estimated by non-linear regression using the Levenberg-Marquardt method of CurveExpert 1.4 (Hyams 2010). The effect of varying mealybug density on the number of parasitized hosts, the proportion of parasitized hosts per capita, number of offspring produced, and sex ratio was analyzed with ANOVA, and means were separated with Tukey tests using SAS 9.4 (SAS Institute 2015).

\section{Effect of parasitoid density on their fecundity}

Third instar mealybugs were collected from rearing cages and placed in groups of 120 on a leaf of waterleaf ( $T$. triangulare). The leaf then was placed inside a petri dish ( $\mathrm{d}$ $=9 \mathrm{~cm}, \mathrm{t}=1.5 \mathrm{~cm}$ ). Parasitoid females aged two days old 
with the treatment of densities $(1,2,4,6$, or 8$)$ were gently introduced into each petri dish and fed with a drop of $10 \%$ honey on the base of the petridish. The parasitoids were allowed to forage and oviposit for $24 \mathrm{~h}$, and then the adult parasitoids were removed. Mealybugs were dissected on an object-glass in a drop of physiological solution of $\mathrm{NaCl}$. The number of parasitoid eggs found in each host was recorded. Treatments in this experiment were replicated 10 times. The total number of eggs oviposited and the number of eggs oviposited per female, as well as the level of superparasitism, were analyzed with ANOVA, and means were separated with Tukey tests using SAS 9.4 (SAS Institute 2015).

\section{Effect of parasitoid density on parasitism, progeny production and sex ratio}

Petri dishes of 120 mealybugs and parasitoids were prepared as described above. Each group of the exposed mealybugs was transferred onto waterleaf cutting and placed into a cage made of a transparent plastic cylinder $(\mathrm{d}$ $=3 \mathrm{~cm}, \mathrm{~h}=3.5 \mathrm{~cm}$ ) with the top covered with nylon mesh. Ten days later, the number of mealybugs parasitized (mummies) were recorded. After two weeks, the cages were checked on a daily basis to collect and record progeny emergence and sex ratio (proportion of females). The total number of parasitized mealybugs and number of parasitized mealybugs per parasitoid were analyzed with ANOVA and means were separated with Tukey tests using SAS 9.4 (SAS Institute 2015).

The per capita searching efficiency (a) of the parasitoids at different parasitoid densities was estimated per replicate according to the Nicholson equation (Hassell 2000):

$$
\mathrm{a}=(1 / \mathrm{PT}) \ln \left[\mathrm{N}_{\mathrm{t}} /\left(\mathrm{N}_{\mathrm{t}}-\mathrm{N}_{\mathrm{a}}\right]\right.
$$

where $\mathrm{P}$ is the number of parasitoids, $\mathrm{T}$ is the duration of experiment (i.e. $24 \mathrm{~h}$ ), $\mathrm{N}_{\mathrm{t}}$ is the total number of mealybugs available $(=120)$ and $\mathrm{Na}$ is the total number of mealybugs parasitized. Searching efficiency was fitted to linear regression by the least square method using the inductive model of Hassell and Varley (Hassell 2000):

$$
\mathrm{a}=\mathrm{QP}^{-\mathrm{m}} \text { or } \log \mathrm{a}=\log \mathrm{Q}-\mathrm{m} \log \mathrm{P}
$$

A is the searching efficiency of the parasitoid, Q is the quest constant (intercept of the regression line), and $\mathrm{m}$ is the mutual interference (slope of the regression line). Regression analysis was performed using MINITAB version 17.1.0 (Minitab 2013).

\section{RESULTS AND DISCUSSION}

\section{Effect of host density on parasitism, progeny, and sex ratio}

The total number of mealybugs parasitized by single $A$. lopezi females increased significantly ( $\mathrm{F}$ 5, 114 $=18.46$; $\mathrm{P}<0.001$ ) from 1.35 to 15.80 mealybugs with an increasing host density from 2 to 100 mealybugs, respectively (Table 1). In contrast, the proportion of hosts parasitized decreased monotonically with the increase in host density ( $F$, $\left.{ }_{114}=4.94 ; \mathrm{P}<0.001\right)$. The wasp-mealybug ratio and the offspring production increased significantly from 1:2 to $1: 100\left(\mathrm{~F}_{5,114}=10.71 ; \mathrm{P}<0.001\right)$ and from 1.35 up to 10.45 , respectively. The sex ratios at different host densities did not differ significantly $\left(\mathrm{F}_{5,114}=0.42 ; \mathrm{P}=0.9916\right)$, but at the density of 100 nymphs, the sex ratio tended to be slightly female-biased $(67 \%)$. Similar results of the effect of host density on parasitism, progeny, and sex ratio were reported for Anagyrus kamali Moursi parasitizing Maconellicoccus hirsutus Green (Hemiptera: Pseudococcidae) (Sagarra et al. 2000a).

Further analysis using polynomial regression between initial host density (No) and the proportion of hosts parasitized $(\mathrm{Na} / \mathrm{No})$ provided significant negative linear and positive quadratic coefficients (Table 2), indicating a type II functional response of $A$. lopezi to third instar nymphs of $P$. manihoti. The functional response curve shows that parasitism increases with increasing host density until the parasitoid reaches its maximum reproductive capacity (Figure 1). By fitting the data to the Holling disc equation, the searching rate (a) and handling time $\left(\mathrm{T}_{\mathrm{h}}\right)$ were $0.03 \mathrm{~h}^{-1}$ and $1.19 \mathrm{~h}$, respectively. Handling time is defined as the time spent handling and parasitizing the host, and also the time spent cleaning and resting. Hence, the handling time is an important attribute for the reproductive success of a parasitoid (Hassell 2000; Beltra et al. 2015). The ratio of exposure time to handling time $\left(\mathrm{T} / \mathrm{T}_{\mathrm{h}}\right)$ is a theoretical maximum number of hosts parasitized per parasitoid female per unit of time. In our experiment, a single A. lopezi female could parasitize a theoretical maximum of 20.2 mealybugs within $24 \mathrm{~h}$. This predicted value was close to the observed maximum value of 24 mealybugs per day.

The type II functional response is the characteristics of many parasitoids, though the type III functional response has also been reported (Fernandez-Arhex and Corley 2003; Tazerouni et al. 2019). The functional response of Aenasius bambawalei Hayat (Hymenoptera: Encyrtidae) to different densities of Phenacoccus solenopsis Tinsley (Hemiptera: Pseudococcidae) has been determined to be of type II (Feng et al. 2014; Joodaki et al. 2018). Also, type II functional response has been reported for other parasitoids, such as Praon volucre (Haliday) (Hymenoptera: Braconidae) attacking Sitobion avenae (Fabricius) (Hemiptera: Aphididae) (Farhad et al. 2011) and Eretmocerus warrae Naumann and Schmidt (Hymenoptera: Aphelenidae) attacking Trialeurodes vaporariorum (Westwood) (Hemiptera: Aleyrodidae) (Hanan et al. 2017). Type III functional response has been reported for several parasitoids, such as Coccidoxenoides perminutus Girault attacking Planococcus citri (Risso) (de Menezes et al. 2017) and Tamarixia triozae (Burks) (Hymenoptera: Eulophidae) attacking the potato psyllid, Bactericera cockerelli (Sulc) (Hemiptera: Psyllidae) (Yang et al. 2015). 
Table 1. Mean ( \pm SE) of the number and proportion of parasitized mealybugs, number, and sex ratio of progeny produced by Anagyrus lopezi at various host densities

\begin{tabular}{cccccc}
\hline $\begin{array}{c}\text { Parasitoid } \\
\text { density }\end{array}$ & $\begin{array}{c}\text { Host } \\
\text { density }\end{array}$ & $\begin{array}{c}\text { Total number of } \\
\text { parasitized mealybugs }\end{array}$ & $\begin{array}{c}\text { Proportion of mealybugs } \\
\text { parasitized }\end{array}$ & $\begin{array}{c}\text { Number of } \\
\text { progenies }\end{array}$ & $\begin{array}{c}\text { Sex ratio (proportion } \\
\text { of females) }\end{array}$ \\
\hline 1 & 2 & $1.35 \pm 0.13 \mathrm{a} *$ & $0.67 \pm 0.06 \mathrm{a}$ & $1.35 \pm 0.13 \mathrm{a}$ & $0.58 \pm 0.09 \mathrm{a}$ \\
1 & 5 & $2.30 \pm 0.24 \mathrm{a}$ & $0.46 \pm 0.04 \mathrm{~b}$ & $1.80 \pm 0.19 \mathrm{a}$ & $0.57 \pm 0.09 \mathrm{a}$ \\
1 & 10 & $5.80 \pm 0.50 \mathrm{~b}$ & $0.58 \pm 0.05 \mathrm{ab}$ & $4.50 \pm 0.34 \mathrm{~b}$ & $0.58 \pm 0.03 \mathrm{a}$ \\
1 & 20 & $9.00 \pm 0.77 \mathrm{c}$ & $0.45 \pm 0.03 \mathrm{~b}$ & $6.70 \pm 0.63 \mathrm{c}$ & $0.58 \pm 0.05 \mathrm{a}$ \\
1 & 50 & $13.35 \pm 0.95 \mathrm{~d}$ & $0.26 \pm 0.01 \mathrm{c}$ & $8.00 \pm 0.79 \mathrm{c}$ & $0.62 \pm 0.05 \mathrm{a}$ \\
1 & 100 & $15.80 \pm 0.85 \mathrm{~d}$ & $0.15 \pm 0.01 \mathrm{c}$ & $10.45 \pm 0.55 \mathrm{~d}$ & $0.67 \pm 0.03 \mathrm{a}$ \\
\hline
\end{tabular}

Note: *Mean in a column with the same letters are not significantly different at $\mathrm{p} \leq 0.05$

Table 2. Result of logistic regression analysis of the proportion of Phenacoccus manihoti third instars parasitized by Anagyrus lopezi to initial host numbers

\begin{tabular}{lccc}
\hline \multicolumn{1}{c}{ Parameters } & Estimate \pm SE & $\chi^{2}$ & P \\
\hline $\mathrm{P}_{0}$ (Intercept) & $0.6360 \pm 0.1770$ & 12.9241 & 0.0003 \\
$\mathrm{P}_{1}$ (Linear) & $-0.0408 \pm 0.0076$ & 28.4141 & $<0.001$ \\
$\mathrm{P}_{2}$ (Quadratic) & $0.00018 \pm 0.00006$ & 7.7588 & 0.0053 \\
\hline
\end{tabular}

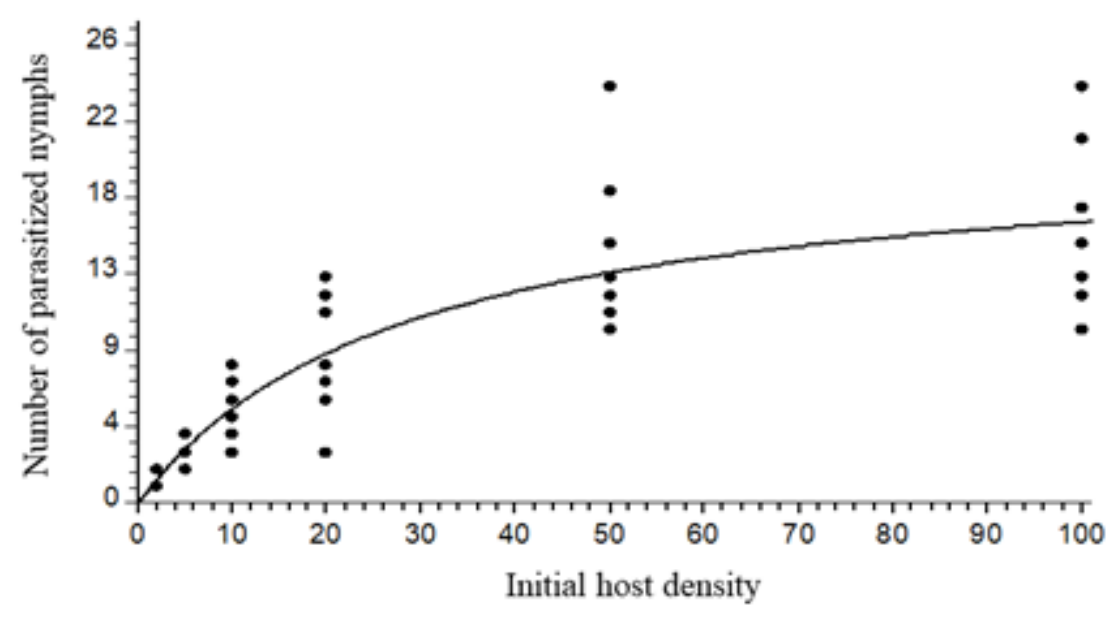

Figure 1. Functional response of Anagyrus lopezi to various host densities

Parasitoid with a type II functional response exerts an inverse, density-dependent action on the pest, whereas a parasitoid with a type III functional response acts in a positive, density-dependent manner. Therefore, a parasitoid with a type III functional response could be a better regulator agent than one having a type II functional response, which can destabilize the pest-natural enemy interaction (Dunn and Hovel 2020). The relative rarity of type III functional response may be an experimental artifact (van Lenteren and Bakker 1978). In natural field conditions, natural enemies can move freely to patches with high densities of hosts, but, in laboratory conditions, natural enemies are forced to remain in a patch for a fixed length of time; therefore, under laboratory conditions, the type III functional response is less common than the type II (He and Wang 2014). Anagyrus kamali exhibited type III functional response when the parasitoids were allowed to determine their residence in the experimental arenas
(Sagarra et al. 2000a). In contrast, the parasitoids enclosed within the arenas for the entire experimental duration showed a type II functional response. He and Wang (2014) demonstrated that parasitoid Platygaster demades Walker (Hymenoptera: Platygastridae) attacking Dasineura mali Kieffer (Diptera: Cecodomyiidae) displayed a type II functional response in the laboratory, but showed a type III in the field where females were able to freely search and disperse. The reports of type II functional response in $A$. lopezi and other parasitoid species (Farhad et al. 2011; Hanan et al. 2017) might be due to a restrictive experimental arena (van Lenteren and Bakker 1978). The form of functional response on its own does not determine the success or failure of parasitoids in biological control (Fernandez-Arhex and Corley 2003; Tazerouni et al. 2019). Other factors like a numerical response, intrinsic growth rates, host patchiness, competition, as well as abiotic and biotic factors such as temperature and host plant also affect 
the efficacy of natural enemies in pest management (Shishehbor and Zandi-Sohani 2011; Yang et al. 2015; Joodaki et al. 2018).

\section{Effect of parasitoid density on fecundity, parasitism, and progeny production}

The total number of eggs oviposited increased significantly ( $\left.\mathrm{F}_{4}, 45=92.49 ; \mathrm{P}<0.001\right)$ from the female density of one to eight (Table 3). At a density of eight female parasitoids, an average of $49.30 \pm 2.24$ eggs was laid by the eight parasitoids. This was significantly greater than the total oviposition at the density of six females (average of $37.20 \pm 0.82 \mathrm{eggs}$ ), which was significantly greater than oviposition at the density of four females (average of $25.70 \pm 1.78 \mathrm{eggs}$ ). At the density of one female, an average of $14.30 \pm 1.15$ eggs was oviposited over a $24 \mathrm{~h}$ period. This was not significantly different from the total number of eggs oviposited by two females, but it was significantly less than oviposition at the densities of 4,6 , and 8 parasitoids. The number of eggs oviposited per female $A$. lopezi differed significantly $\left(\mathrm{F}_{4,45}=36.19\right.$; $\mathrm{P}<0.001)$ among densities. A decrease in the oviposition rate per female parasitoid occurred with the increase in female density, dropping from $14.30 \pm 1.16 \mathrm{eggs} /$ female at the density of one female to $6.42 \pm 0.44 \mathrm{eggs} / \mathrm{female}$ at the density of four females. Sagarra et al. (2000b) reported similarly that fewer eggs per female were laid by Anagyrus kamali Moursi as the number of wasps increased in a patch. The number of eggs oviposited per parasitized mealybug was also significantly $\left(\mathrm{F}_{4,45}=13.15 ; \mathrm{P}<0.001\right)$ affected by female densities. The number of eggs oviposited per parasitized mealybug was not significantly different between densities of one and two parasitoids, which were $1.05 \pm 0.02$ and $1.04 \pm 0.01$, respectively. However, at the density of 4,6 , and 8 female parasitoids, the number of eggs per parasitized mealybug was significantly higher than at densities of 1 to 2 , which were $1.27 \pm 0.07,1.26 \pm$ 0.04 , and $1.37 \pm 0.03$, respectively. Female parasitoid density can also affect the timing of parasitism and development duration of progeny as reported for Sclerodermus pupariae Yang et Yao (Hymenoptera: Bethylidae), a parasitoid of Agrilus planipennis Fairmaire (Coleoptera: Cerambycidae) (Gao et al. 2016).

Intraspecific competition between parasitoids can occur at the larval stage or the adult stage with different consequences for the host-parasitoid interaction. Since $A$. lopezi is a solitary endoparasitoid, competition between larvae in superparasitized hosts results in all but one dying, and thus high levels of superparasitism would be a disadvantage for mass production of the parasitoid (Lou et al. 2014). In our study, superparasitism of $A$. lopezi increased significantly $\left(\mathrm{F}_{4}, 45=18.89 ; \mathrm{P}<0.001\right)$ with the increasing density of conspecific parasitoids. Single parasitoid female caused on average $5.34 \%$ superparasitism, whereas at densities of eight females, superparasitism was significantly $\left(\mathrm{F}_{4,45}=18.80 ; \mathrm{P}<0.001\right)$ higher $(33.73 \%)$. Superparasitism occurred regardless of host density, as also reported for A. kamali (Sagarra et al. 2000a). Female wasps have a propensity to superparasitize their hosts as the average number of eggs per parasitized mealybug was greater than one egg (Table 3, column 5), as previously reported by Adriani et al. (2016). Suma et al. (2012) also found that Anagyrus vladimiri (Triapitsyn) (=Anagyrus sp. nr. pseudococci) oviposited on average more than one egg per parasitized mealybug. They found an apparent relationship between the number of eggs laid by the parasitoid and the level of resistance of the host mealybugs, as revealed by the number of encapsulated eggs. This supports the hypothesis that superparasitism might be used by the parasitoid as a strategy for overcoming host immune response (encapsulation) (Suma et al 2012; Luna et al. 2016).

Intraspecific competition among searching wasps can lead to a direct density-dependent reduction in parasitism (Luo et al. 2014; Eliopoulos et al. 2017). The results of the present study show that parasitism by single female parasitoids decreased with increasing parasitoid density (Table 4). The average number of mealybugs parasitized per individual $A$. lopezi female decreased significantly $\left(\mathrm{F}_{4}\right.$, ${ }_{45}=20.32 ; \mathrm{P}<0.001$ ) from 14.20 to 4.37 when parasitoid densities increased from 1 to 8 , respectively. Such reduction in the number of mealybugs parasitized is indicative of mutual interference among foraging parasitoids in the same arena (Feng et al. 2014; Lin et al. 2018). Accordingly, the per capita searching efficiency of the parasitoid also reduced significantly $\left(\mathrm{F}_{4,45}=14.40\right.$; $\mathrm{P}<0.001$ ) from 0.0053 to 0.0019 with the increase in parasitoid density from 1 to 8 . By fitting data to the equation $\log \mathrm{a}=\log \mathrm{Q}-\mathrm{m} \log \mathrm{P})$, the searching efficiency of the parasitoid (a) was negatively related to parasitoid density (P) as $\log \mathrm{a}=-2.3349-0.5208 \log \mathrm{P}$. The mutual interference coefficient (slope of the regression line) was estimated to be $\mathrm{m}=-0.52$. The negative value of the regression slope indicates an inverse relationship between parasitoid density and per capita searching efficiency, or searching efficiency decreases with increasing parasitoid density. Mutual interference appears when competition for a common resource leads to a decrease in searching efficiency of the individual parasitoid (Hassell 2000; Skovgard and Nachman 2015; Yazdani and Keller 2015). Iranipour et al. (2020) reported a decrease in searching rate of parasitoid Trissolcus vassilievi (Mayr) (Hymenoptera: Platygastridae) and a 2-fold increase in host survival of Eurygaster integriceps Puton (Hemiptera: Scutelleridae) at higher wasp densities.

Increasing conspecific numbers had a significant influence on the reproduction patterns of A. lopezi. Progeny production increased significantly $\left(\mathrm{F}_{4,45}=10.78 ; \mathrm{P}<0.001\right)$ from the female density of 1 to 8 . The progeny from the 6 and 8 females parasitoids were about 3-4 higher than those from 1 female (Table 5), suggesting a marginal decrease in the efficiency of the individual parasitoid at high density. Due to high mutual interference at higher parasitoid densities, the progeny per female decreased with increasing parasitoid density. Repeated puncturing of hosts might induce more mortality in the mealybug population, causing a decrease in the progeny emergence as also reported for $A$. kamali (Sagarra et al. 2000b). Parasitoids foraging alone produced an average progeny of 6.41 , whereas parasitoids foraging in groups of 8 produced only 3.05. The sex ratio 
of progenies was not significantly different $\left(\mathrm{F}_{4,45}=1.21\right.$; $\mathrm{P}=0.321$ ) across female densities, varying from $0.75 \pm 0.04$ (density $=$ one parasitoid) to $0.57 \pm 0.01$ (density $=8$ parasitoids). The stability of the sex ratio, regardless of the female wasp density, was reported previously by van Dijken et al. (1989), who concluded that local mate competition (LMC) does not occur in A. lopezi. Sagarra et al. (2000b) reported a similar phenomenon for A. kamali.

Table 3. Mean ( \pm SE) of the number of total eggs oviposited, eggs oviposited by each female, eggs per parasitized mealybug and rate of superparasitism at various densities of Anagyrus lopezi

\begin{tabular}{cccccc}
\hline $\begin{array}{c}\text { Parasitoid } \\
\text { density }\end{array}$ & $\begin{array}{c}\text { Host } \\
\text { density }\end{array}$ & $\begin{array}{c}\text { Total number of } \\
\text { eggs oviposited }\end{array}$ & $\begin{array}{c}\text { Number of eggs } \\
\text { oviposited per } \\
\text { parasitoid }\end{array}$ & $\begin{array}{c}\text { Number of eggs per parasitized } \\
\text { mealybug }\end{array}$ & $\begin{array}{c}\text { Rate of } \\
\text { superparasitism } \\
(\%)\end{array}$ \\
\hline 1 & 120 & $14.30 \pm 1.15 \mathrm{a}^{*}$ & $14.30 \pm 1.16 \mathrm{a}$ & $1.05 \pm 0.02 \mathrm{a}$ & $5.34 \pm 2.30 \mathrm{a}$ \\
2 & 120 & $19.70 \pm 0.66 \mathrm{a}$ & $9.85 \pm 0.33 \mathrm{~b}$ & $1.04 \pm 0.01 \mathrm{a}$ & $5.73 \pm 1.75 \mathrm{a}$ \\
4 & 120 & $25.70 \pm 1.78 \mathrm{~b}$ & $6.42 \pm 0.44 \mathrm{c}$ & $1.27 \pm 0.07 \mathrm{~b}$ & $22.48 \pm 4.08 \mathrm{~b}$ \\
6 & 120 & $37.20 \pm 0.82 \mathrm{c}$ & $6.20 \pm 0.13 \mathrm{c}$ & $1.26 \pm 0.04 \mathrm{~b}$ & $21.12 \pm 3.06 \mathrm{~b}$ \\
8 & 120 & $49.30 \pm 2.24 \mathrm{~d}$ & $6.16 \pm 0.28 \mathrm{c}$ & $1.37 \pm 0.03 \mathrm{~b}$ & $33.73 \pm 2.15 \mathrm{c}$ \\
\hline
\end{tabular}

Note: *Mean in a column with the same letters are not significantly different at $\mathrm{p} \leq 0.05$

Table 4. Mean ( \pm SE) of the number of total parasitized mealybugs, mealybugs parasitized per wasp, and searching efficiency of Anagyrus lopezi female at various wasp densities

\begin{tabular}{ccccc}
\hline $\begin{array}{c}\text { Parasitoid } \\
\text { density }\end{array}$ & $\begin{array}{c}\text { Host } \\
\text { density }\end{array}$ & $\begin{array}{c}\text { Total number of parasitized } \\
\text { mealybugs }\end{array}$ & $\begin{array}{c}\text { Number of parasitized mealybugs } \\
\text { per parasitoid }\end{array}$ & $\begin{array}{c}\text { Searching efficiency per } \\
\text { parasitoid }\end{array}$ \\
\hline 1 & 120 & $14.20 \pm 1.06 \mathrm{a}$ & $14.20 \pm 1.06 \mathrm{a}$ & $0.0053 \pm 0.0006 \mathrm{a}$ \\
2 & 120 & $17.40 \pm 1.50 \mathrm{a}$ & $8.70 \pm 0.75 \mathrm{~b}$ & $0.0033 \pm 0.0004 \mathrm{~b}$ \\
4 & 120 & $20.70 \pm 1.28 \mathrm{ab}$ & $5.17 \pm 0.32 \mathrm{bc}$ & $0.0021 \pm 0.0006 \mathrm{~b}$ \\
6 & 120 & $30.40 \pm 2.16 \mathrm{bc}$ & $5.06 \pm 0.36 \mathrm{c}$ & $0.0020 \pm 0.0008 \mathrm{~b}$ \\
8 & 120 & $35.01 \pm 3.05 \mathrm{c}$ & $4.37 \pm 0.38 \mathrm{c}$ & $0.0019 \pm 0.0009 \mathrm{~b}$ \\
\hline
\end{tabular}

Note: *Mean in a column with the same letters are not significantly different at $\mathrm{p} \leq 0.05$

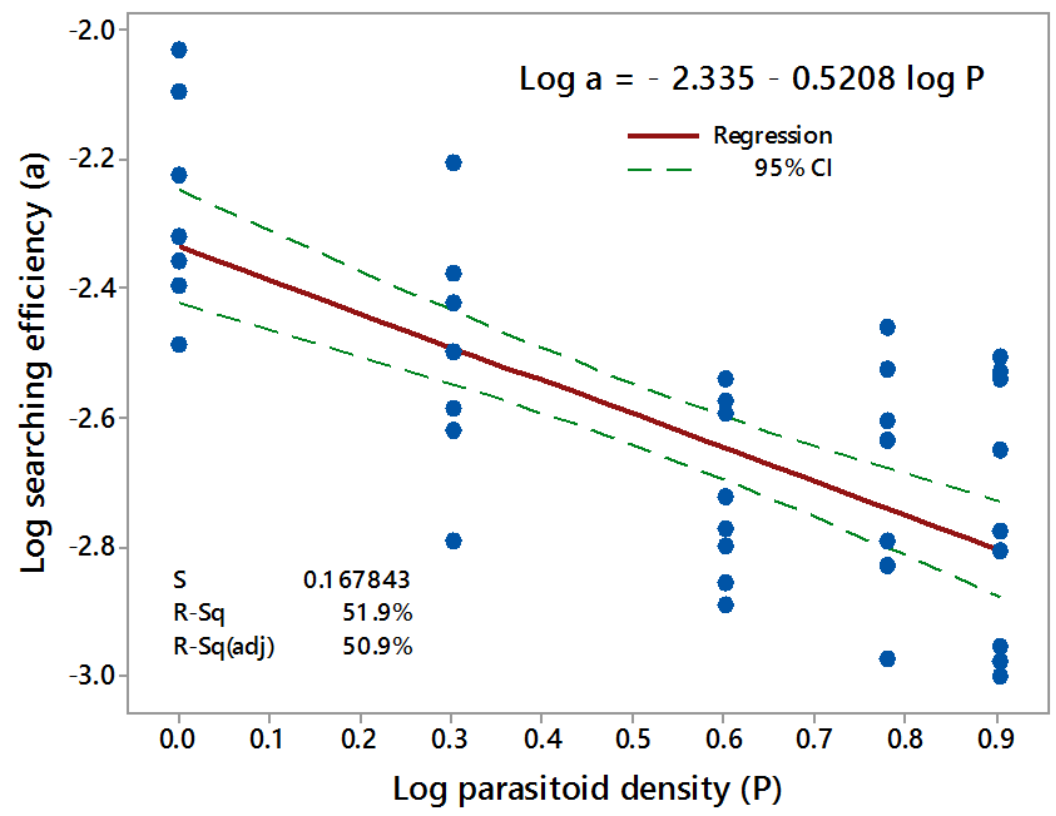

Figure 2. Mutual interference among foraging Anagyrus lopezi females 
Table 5. Mean ( \pm SE) of the number offspring and sex ratio of Anagyrus lopezi at various wasp densities

\begin{tabular}{ccccc}
\hline $\begin{array}{c}\text { Parasitoid } \\
\text { density }\end{array}$ & $\begin{array}{c}\text { Host } \\
\text { density }\end{array}$ & $\begin{array}{c}\text { Total number of } \\
\text { progenies }\end{array}$ & $\begin{array}{c}\text { Number of progenies per } \\
\text { parasitoid }\end{array}$ & $\begin{array}{c}\text { Sex ratio (proportion of } \\
\text { females) }\end{array}$ \\
\hline 1 & 120 & $6.40 \pm 0.91 \mathrm{a}^{*}$ & $6.41 \pm 0.91 \mathrm{a}$ & $0.75 \pm 0.04 \mathrm{a}$ \\
2 & 120 & $9.40 \pm 1.75 \mathrm{a}$ & $4.70 \pm 0.87 \mathrm{a}$ & $0.74 \pm 0.04 \mathrm{a}$ \\
4 & 120 & $12.20 \pm 1.08 \mathrm{ab}$ & $3.86 \pm 0.27 \mathrm{a}$ & $0.69 \pm 0.04 \mathrm{a}$ \\
6 & 120 & $23.20 \pm 1.85 \mathrm{bc}$ & $3.38 \pm 0.01 \mathrm{a}$ & $0.67 \pm 0.04 \mathrm{a}$ \\
8 & 120 & $27.10 \pm 3.20 \mathrm{c}$ & $3.05 \pm 0.40 \mathrm{a}$ & $0.57 \pm 0.01 \mathrm{a}$ \\
\hline
\end{tabular}

Note: *Mean in a column with the same letters are not significantly different at $\mathrm{p} \leq 0.05$

The results of our study indicate that there are mutual interferences when two or more A. lopezi females forage in the same patch. As the density of parasitoids increases in an arena, the searching female spends more time interacting with the conspecific than searching the host (Hassell 2000; Henne and Johnson 2010; Saini and Sharma 2018). Intraspecific competition among the foraging parasitoids can reduce the parasitization level and, ultimately, the efficacy of the given parasitoids (Lou et al. 2014; Poncio et al. 2016; Eliopoulos et al. 2017). Our study reveals that the searching efficiency of $A$. lopezi decreased significantly with the increase in parasitoid density, and the competition was higher at higher parasitoid densities. The negative effect of mutual interference on the progeny production of the parasitoid would undermine the efficiency of the mass-rearing system of A. lopezi in the laboratory. In cassava fields, the variation in host density among patches is much more variable than in laboratory arenas. This is because natural systems include more patches, hosts are present at various developmental stages, and the profitability of patches varies with both in space and in time (Yazdani and Keller 2015). The wasps would have the chance to disperse into rewarding patches and result in a more homogenous distribution among patches, which subsequently affects interference among parasitoids (Okuyama 2016; Iranipour et al. 2020). We suspect that interference would not have a pronounced effect on the efficiency of A. lopezi in the fields. DeLong and Vasseur (2011) suggested that mutual interference is common and mostly intermediate in magnitude.

In conclusion, this study has provided important insights into $A$. lopezi functional response and mutual interference that is unknown until now. Under laboratory conditions, A. lopezi showed a type II functional response to increasing host density. The number of parasitized nymph and offspring per capita females $A$. lopezi decreased with an increasing parasitoid density. Consequently, higher parasitoid densities should be avoided when mass producing A. lopezi.

\section{ACKNOWLEDGEMENTS}

This work was supported by the Ministry of Research, Technology and Higher Education of the Republic of Indonesia under PMDSU (Program Magister Menuju Doktor untuk Sarjana Unggul) program.

\section{REFERENCES}

Adriani E, Rauf A, Pudjianto. 2016. Encapsulation rates of parasitoid Anagyrus lopezi (De Santis) (Hymenoptera: Encyrtidae) by cassava mealybug, Phenacoccus manihoti Matile-Ferrero (Hemiptera: Pseudococcidae). J Entomol Indon 13 (3): 147-155. [Indonesian]

Bellotti A, Campo BVH, Hyman G. 2012. Cassava production and pest management: Present and potential threats in a changing environment. Trop Plant Biol 5: 39-72. DOI: 10.1007/s12042-011-9091-4.

Beltra A, Soto A, Tena A. 2015. How a slow-ovipositing parasitoid can succeed as a biological control agent of the invasive mealybug Phenacoccus peruvianus: Implication for future classical and conservation biological control programs. BioControl 60 (4): 473484. DOI: $10.1007 / \mathrm{s} 10526-015-9663-6$.

de Menezes KO, de Araujo Fernandes MH, Paz HHR, de Souza AM, Torres JB, de Morais Oliveira JE. 2017. Parasitismo de cochonilhafarinhenta Planococcus citri (Hemiptera: Pseudococcidae) por Coccidoxenoides perminutus (Hymenoptera: Encyrtidae). Rev Ceres Vicosa 64 (5): 486-491. [Portuguese]

DeLong JP, Vasseur DA. 2011. Mutual interference is common and mostly intermediate in magnitude. BMC Ecol 11: 1-8. DOI: 10.1186/1472-6785-11-1.

Dunn RP, Hovel KA. 2020. Predator type influences the frequency of functional responses to prey in marine habitats. Biol Lett 16: 20190758. DOI: 10.1098/rsbl.2019.0758.

Eliopoulos PA, Kapranas A, Givropoulou EG, Hardy LCW. 2017. Reproductive efficiency of the bethylid wasp Cephalonomia tarsalis: The influences of spatial structure and host density. Bull Entomol Res 107 (2): 139-147.

Fanani MZ, Rauf A, Maryana N, Nurmansyah A, Hindayana D. 2019. Geographic distribution of the invasive mealybug Phenacoccus manihoti and its introduced parasitoid Anagyrus lopezi in parts of Indonesia. Biodiversitas 20 (12): 3751-3757. DOI: 10.13057/biodiv/d201238.

Fanani MZ, Rauf A, Maryana N, Nurmansyah A, Hindayana D. 2020. Parasitism disruption by ants of Anagyrus lopezi (Hymenoptera: Encyrtidae), parasitoid of cassava mealybug. Biodiversitas 21 (6): 2337-2343. DOI: 10.13057/biodiv/d210601.

Farhad A, Talebi AA, Fathipour Y. 2011. Foraging behaviour of Praon volucre (Hymenoptera: Braconidae) a potential parasitoid of Sitobion avenae (Hemiptera: Aphididae) on wheat. Psyche: J Entomol 2011: 868546. DOI: $10.1155 / 2011 / 868546$.

Feng DD, Li P, Zhou ZS, Xu ZF. 2014. Parasitism potential of Aenasius bambawalei on the invasive mealybug Phenacoccus solenopsis. Biocontrol Sci Technol 24 (11): 1333-1338. DOI: 10.1080/09583157.2014.939946.

Fernandez-Arhex V, Corley JC. 2003. The functional response of parasitoids and its implication for biological control. Biocontrol Sci Technol 13 (4): 403-413. DOI: 10.1080/0958315031000104523.

Gao SK, Wei K, Tang YL, Wang XY, Yang ZQ. 2016. Effect of parasitoid density on the timing of parasitism and development duration of progeny in Sclerodermus pupariae (Hymenoptera: Bethylidae). Biol Control 97: 57-62. DOI: 10.1016/j.biocontrol.2016.03.003.

Graziosi I, Minato N, Alvarez E, Ngo DT, Hoat TX, Aye TM, Pardo JM, Wongtiem P, Wyckhuys KAG. 2016. Emerging pests and diseases of Southeast Asia cassava: A comprehensive evaluation of geographic priorities, management options and research needs. Pest Manag Sci 72 (6): 1071-1089. DOI: $10.1002 / \mathrm{ps} .4250$. 
Hanan A, He XZ, Wang Q. 2017. Insight into the success of whitefly biological control using parasitoids: Evidence from the Eretmocerus warrae - Trialeurodes vaporariorum system. Pest Manag Sci 73 (11): 2294-2301. DOI: $10.1002 / \mathrm{ps} .4612$.

Hassell MP. 2000.Spatial and Temporal Dynamics of Host-Parasitoid Interactions. Oxford University Press, Oxford, UK.

He X, Wang Q. 2014. Demographic dynamics of Platygaster demades in response to host density. Biol Control 72: 46-53. DOI: 10.1016/j.biocontrol.2014.02.008

Henne DC, Johnson SJ. 2010. Laboratory evaluation of aggregation, direct mutual interference, and functional response characteristics of Pseudacteon tricuspis Borgmeier (Diptera: Phoridae). Biol Control 55 (1): 63-71. DOI: 10.1016/j.biocontrol.2010.07.001

Hyams DG. 2010. CurvExpert software. http://www.curveexpert.net

Iranipour S, BenaMoleai P, Asgari S, Michaud JP. 2020. Foraging egg parasitoids, Trissolcus vassilievi (Hymenoptera: Platygastridae), respond to host density and conspecific competitors in a patchy laboratory environment. J Econ Entomol 112 (2): 760-769.

Joodaki R, Zandi-Sohani N, Zarghami S, Yarahmadi F. 2018 Temperature-dependent functional response of Aenasius bambawalei (Hymenoptera: Encyrtidae) to different population densities of the cotton mealybug Phenacoccus solenopsis (Hemiptera: Pseudococcidae). Eur J Entomol 115: 326-331. DOI: 10.14411/eje.2018.032

Juliano SA. 2001. Nonlinear curve fitting: Predation and functional response curves. In: Scheiner SM, Gurevitch J (eds). Design and Analysis of Ecological Experiments, 2nd ed. Chapman and Hall, New York, NY

Le TTN, Graziosi I, Cira TM, Gates MW, Parker L, Wyckhuys KAG. 2018. Landscape context does not constrain biological control of Phenacoccus manihoti in intensified cassava systems of southern Vietnam. Biol Control 121: 129-139. DOI: 10.1016/j.biocontrol.2018.02.011

Lin L, Ali S, Wu J. 2018. Influences of varying host: Parasitoid ratios on parasitism of whitefly by three different parasitoid species. Egypt $\mathrm{J}$ Biol Pest Conttrol 28: 59. DOI: 10.1186/s41938-018-0050-3

Lou YG, Zhang GR, Zhang WQ, Hu Y, Zhang J. 2014. Biological control of rice insect pests in China. Biol Control 68: 103-116.

Luna MG, Desneux N, Schneider MI. 2016. Encapsulation and selfsuperparasitism of Pseudapanteles dignus (Muesebeck) (Hymenoptera: Braconidae), a parasitoid of Tuta absoluta (Meyrick) (Lepidoptera: Gelechiidae). PLoS ONE 11 (10): e0163196. DOI: 10.1371/journal.pone.0163196

Luo SP, Li HM, Lu YH, Zhang F, Haye T, Kuhlmann U, Wu K. 2014. Functional response and mutual interference of Peristenus spretus (Hymenoptera: Braconidae), a parasitoid of Apolygus lucorum (Heteroptera: Miridae). Biocontrol Sci Technol 24 (3): 247-256. DOI: 10.1080/09583157.2013.855703

Minitab 17 Statistical Software. 2013. Minitab Inc., State College, PA.

Muniappan R, Shepard BM, Watson GW, Carner GR, Rauf A, Sartiami D, Hidayat P, Afun JVK, Goergen G, Rahman AKMZ. 2011. New records of invasive insects (Hemiptera: Sternorrhyncha) in Southern Asia and West Africa. J Agr Urban Entomol 26 (4): 167-174.

Okuyama T. 2016. Parasitoid aggregation and interference in hostparasitoid dynamics. Ecol Entomol 41 (4): 473-479.

Parsa S, Kondo T, Winotai A. 2012. The cassava mealybug (Phenacoccus manihoti) in Asia: First records, potential distribution, and an identification key. PLoS ONE 7 (10): e47675. DOI: 10.1371/journal.pone.0047675

Poncio S, Montoya P, Cancino J, Nava DE. 2016. Determining the functional response and mutual interference of Utetes anastrephae (Hymenoptera: Braconidae) on Anastrepha obliqua (Diptera: Tephritidae) larvae for mass rearing purposes. Ann Entomol Soc Am 109 (4): 518-525. DOI: 10.1093/aesa/saw031.

Rosenbaum B, Rall BC. 2018. Fitting functional responses: Direct parameter estimation by simulating differential equations. Methods Ecol Evol 9: 2076-2090. DOI: 10.1111/2041-210X.13039.

Sagarra LA, Vincent C, Peters NF, Stewart RK. 2000a. Effect of host density, temperature, and photoperiod on the fitness of Anagyrus kamali, a parasitoid of the hibiscus mealybug Maconellicocus hirsutus. Entomol Exp Appl 96 (2): 141-147. DOI: 10.1046/j.15707458.2000.00689.x.

Sagarra LA, Vincent C, Stewart RK. 2000b. Mutual interference among female Anagyrus kamali Moursi (Hymenoptera: Encyrtidae) and its impact on fecundity, progeny production and sex ratio. Biocontrol Sci Technol 10 (3): 239-244. DOI: 10.1080/09583150050044510.

Saini A, Sharma PL. 2018. Functional response and mutual interference of Cotesia vestalis (Hymenoptera: Braconidae) on Plutella xylostella (Lepidoptera: Plutellidae). J Entomol Sci 53 (2): 162-170.

SAS Institute. 2015. SAS 9.4 User's ${ }^{\circledR}$ Guide: Statistic. SAS Institute, Cary, NC.

Shishehbor P, Zandi-Sohani N. 2011. Investigation on functional and numerical responses of Encarsia acaudaleyrodis parasitizing Bemisia tabaci on cucumber. Biocontrol Sci Technol 21 (3): 271-280.

Skovgard HG, Nachman. 2015. Effect of mutual interference on the ability of Spalangia cameroni (Hymenoptera: Pteromalidae) to attack and parasitize pupae of Stomoxys calcitrans (Diptera: Muscidae). Environ Entomol 19 (4): 1076-1084. DOI: 10.1093/ee/nvv096

Sreenivas AG, Hardy ICW. 2016. Mutual interference reduces offspring production in a brood-guarding betthylid wasp. Entomol Exp App 159 (2): 260-269. DOI: 10.1111/eea.12412.

Suma P, Mansour R, Russo A, Torre IL, Bugila AAA, Franco JC. 2012. Encapsulation rates of the parasitoid Anagyrus sp. nr. pseudococci by three mealybug species (Hemiptera: Pseudococcidae). Phytoparasitica 40: 11-16. DOI: 10.1007/s12600-011-0199-8.

Tazerouni Z, Talebi AA, Rezaei M. 2019. Functional response of parasitoids: Its impact on biological control. In: Donnelly E (eds). Parasitoids: Biology, Behavior, and Ecology. Nova Science Publishers Inc., New York.

Thancharoen A, Lankaew S, Moonjuntha $\mathrm{P}$, Wongphanuwat $\mathrm{T}$, Sangtongpraow B, Ngoenklan R, Kittipadakul P, Wyckhuys KAG. 2018. Effective biological control of an invasive mealybug pest enhances root yield in cassava. J Pest Sci 91 (10): 1199-1211. DOI: 10.1007/s10340-018-1012-y.

van Dijken MJ, van Alphen JJM, van Stratum P. 1989. Sex allocation in Epidinocarsis lopezi: Local mate competition. Entomol Exp Appl 52 (3): 249-255. DOI: 10.1111/j.1570-7458.1989.tb01274.x.

van Lenteren JC, Bakker K. 1978. Behavioral aspects of the functional response of a parasite (Pseudeucoila bochei Weld) to its host (Drosophila melanogaster). Neth J Entomol 28 (2): 213-233. DOI: 10.1163/002829678X00062.

Winotai A, Goergen G, Tamo M, Neuenschwander P. 2010. Cassava mealybug has reached Asia. Biocontrol News Inf 31 (2): 10-11.

Wyckhuys KAG, Rauf A, Ketelaar J. 2014. Parasitoid introduced into Indonesia: Part of a region-wide campaign to tackle emerging cassava pests and diseases. Biocontrol News Inf 35 (4): 35-37.

Wyckhuys KAG, Wongtiem P, Rauf A, Thancharoen A, Heimpel GE, Le NTT, Fanani MZ, Gurr GM, Lundgren JG, Burra DD, Palao LK, Hyman G, Graziosi I, Le VX, Mock MJW, Tscharntke T, Wratten SD, Nguyen LV, You M, Lu Y, Ketelaar JW, Goergen G, Neuenschwander P. 2018. Continental-scale suppression of an invasive pest by a host-specific parasitoid underlines both environmental and economic benefits of arthropod biological control. PeerJ 6: e5796. DOI: 10.7717/peerj.5796.

Yang XB, Campos-Figueroa M, Silva A, Henne DC. 2015. Functional response, prey stage preference, and mutual interference of the Tamarixia triozae (Hymenoptera: Eulophidae) on tomato and bell pepper. J Econ Entomol 108 (2): 414-424.

Yazdani M, Keller M. 2015. Mutual interference in Dolichogenidea tasmanica (Cameron) (Hymenoptera: Braconidae) when foraging for patchily-distributed light brown apple moth. Biol Control 86: 1-6. DOI: 10.1016/j.biocontrol.2015.01.004.

Yonow T, Kriticos DJ, Ota N. 2017. The potential distribution of cassava mealybug (Phenacoccus manihoti), a threat to food security for the poor. PLoS ONE 12 (3): e0173265. DOI: 10.1371/journal.pone.0173265. 